\title{
Analisis Efisiensi Biaya dengan Menggunakan Metode Transportasi pada Pendistribusian Barang PT. XYZ
}

\author{
Danang Prihandoko \\ dprihandoko@binus.ac.id \\ Program Studi Ilmu Manajemen \\ Universitas Bina Nusantara \\ Elvina \\ elvinawjy17@gmail.com \\ Jurusan Manajemen \\ Universitas Bina Nusantara \\ Dedy Hartono \\ deddyhart07@gmail.com \\ Jurusan Manajemen \\ Universitas Bina Nusantara
}

\begin{abstract}
This research purpose is to streamline the cost of PT. XYZ goods shipping. The company will know the cost efficiency between using the third party transportation services or their own transportation. This reseacrh method is descriptive, the required data is obtained by conducting a survey at this company. Analysis data in this research are using Transportation Method. To get the optimal shipping cost, company had using transportation services by using Transportation Method with North West Corner (NWC), Least Cost, and Vogel's Approximation Method (VAM) approaches. And result of this research is indicate that the method of company using on their own transportation is not optimal, and the company can streamline the cost if using third party transportation services rather than using their own transportation to the destination area. To get the optimal cost, company ought to use Transportation Method.
\end{abstract}

Keywords: Efficiency; Transportation Method; North West Corner; Least Cost; Vogel's Approximation Method

\section{Pendahuluan}

Pada saat ini, persaingan dalam industri perdagangan semakin kompetitif untuk menjadi yang terbaik dalam pemberian kualitas produk yang dihasilkan. Kemajuan teknologi dan perekonomian menjadi pengaruh yang cukup besar dalam tingkat persaingan yang ada dalam industri perdagangan saat ini. Hal itu juga dirasakan dalam bidang Teknologi Informasi dan Komunikasi (TIK) di Indonesia yang akan berlomba-lomba menjadi perusahaan untuk dapat menguasai pasar dan berusaha menentukan langkah yang tepat dalam menjalankan sistem serta strategi operasional secara keseluruhan di dalam perusahaan untuk bisa bersaing. Persaingan yang semakin kompetitif mendorong setiap perusahaan agar mampu mempertahankan kelangsungan hidup perusahaan dengan cara mengatur aktivitas operasi dalam perusahaan tersebut. Selain mementingkan penjualan, perusahaan juga harus memperhatikan dan mengefesiensikan atau mengoptimalkan biaya operasional yang sering dikeluarkan. Tabel 1 di bawah ini adalah data kompetitor PT. XYZ. 
Analisis Efisiensi Biaya dengan Menggunakan Metode Transportasi

pada Pendistribusian Barang PT. XYZ

Tabel 1. Data Kompetitor PT. XYZ

\begin{tabular}{|c|c|c|c|c|c|}
\hline Nama Perusahaan & $\begin{array}{l}\text { Tahun } \\
\text { Berdiri }\end{array}$ & Alamat & Produk & $\begin{array}{c}\text { Jumlah } \\
\text { Karyawan }\end{array}$ & Tujuan Bisnis \\
\hline PT. XYZ & 1978 & $\begin{array}{l}\text { Jl. Raya } \\
\text { Perjuangan } \\
\text { No. 21 } \\
\text { Gedung } \\
\text { Sastra Graha } \\
\text { LT. 3, Jakarta } \\
\text { Barat }\end{array}$ & $\begin{array}{l}\text { Panasonic } \\
\text { (Itcomm) }\end{array}$ & $\begin{array}{l}\text { Lebih dari } \\
250 \\
\text { karyawan }\end{array}$ & $\begin{array}{l}\text { Dapat } \\
\text { mendistribusikan } \\
\text { produk Informasi dan } \\
\text { Teknologi kami } \\
\text { bersama dengan Mitra } \\
\text { Dealer nasional dan } \\
\text { lokal kami yang } \\
\text { memiliki saluran } \\
\text { distribusi dan } \\
\text { distribusi yang kuat } \\
\text { dan kompeten dalam } \\
\text { bidang ICT. }\end{array}$ \\
\hline $\begin{array}{l}\text { PT. Synnex } \\
\text { Metrodata } \\
\text { Indonesia }\end{array}$ & 2011 & $\begin{array}{l}\text { APL Tower } \\
42^{\text {nd }} \text { Floor } \\
\text { Suite 1-8, Jl. } \\
\text { Letjen S. } \\
\text { Parman } \\
\text { Kav.28 }\end{array}$ & $\begin{array}{l}\text { Cisco, Intel, } \\
\text { Dell, dan } \\
\text { lain-lain }\end{array}$ & - & $\begin{array}{l}\text { SMI mendistribusikan } \\
\text { berbagai produk TIK } \\
\text { kepada } \\
\text { agen, dealer atau resel } \\
\text { ler dalam jumlah besar } \\
\text { (grosir) }\end{array}$ \\
\hline $\begin{array}{l}\text { PT. Gifera Odo } \\
\text { Technology }\end{array}$ & 2014 & $\begin{array}{l}\text { Office } 818 \mathrm{~A}, \\
\text { Jl. Jend. } \\
\text { Sudirman Kv. } \\
\text { 52-53 SCBD } \\
\text { Jakarta } \\
\text { Selatan }\end{array}$ & $\begin{array}{l}\text { Avaya, } \\
\text { Cisco, dan } \\
\text { lain-lain }\end{array}$ & 15 karyawan & $\begin{array}{l}\text { Kami memberikan } \\
\text { solusi ICT dengan } \\
\text { produk produk|terbaik } \\
\text { dengan harga yang } \\
\text { kompeitif. Tidak } \\
\text { hanya menjual produk, } \\
\text { kami memiliki tim } \\
\text { yang ahli, } \\
\text { berpengalaman, dan } \\
\text { tersertifikasi mulai } \\
\text { dari tahap desain } \\
\text { sampai dengan } \\
\text { implementasi. }\end{array}$ \\
\hline $\begin{array}{l}\text { PT. Datacomindo } \\
\text { Mitrausaha }\end{array}$ & 1994 & $\begin{array}{l}\text { Kebon Jeruk } \\
\text { Permai Blok } \\
\text { A7, Jl. Kebon } \\
\text { Jeruk Raya } \\
\text { No.7 }\end{array}$ & $\begin{array}{l}\text { Panasonic, } \\
\text { NEC, } \\
\text { Avaya, } \\
\text { Transtel, } \\
\text { Yeastar, } \\
\text { dan lain- } \\
\text { lain }\end{array}$ & 50 karyawan & $\begin{array}{l}\text { Memberikan solusi } \\
\text { dalam industri } \\
\text { telekomunikasi untuk } \\
\text { industri komersil dan } \\
\text { konsumer melalui tim } \\
\text { kami } \\
\text { yang berpengalaman, } \\
\text { dan jaringan luas } \\
\text { penjualan eceran dan } \\
\text { grosir maupun jalur } \\
\text { pemasaran, seperti } \\
\text { toko retail, pasar } \\
\text { modern, ecommerce } \\
\text { (perdagangan } \\
\text { elektronik), dan jalur } \\
\text { antar bisnis. }\end{array}$ \\
\hline
\end{tabular}

Sumber: Website Perusahaan (2019)

PT. XYZ berdiri pada tahun 1978, telah lebih dari 39 tahun perusahaan ini dalam distribusi produk teknologi informasi dan komunikasi. Perusahaan ini merupakan distributor tunggal di Indonesia untuk produk-produk bermerek dagang Panasonic yang berlokasi di Kebon Jeruk, Jakarta Barat. Perusahaan ini mendistribusikan berbagai produk tersebut ke konsumen seperti 
toko-toko elektronik di berbagai daerah Jabodetabek dan kota besar lainnya. Perusahaan menyebutkan adanya masalah pada tahun 2018 untuk wilayah Jabodetabek, karena pendistribusian ke wilayah Jabodetabek menurun dari tahun sebelumnya, tetapi biaya yang dikeluarkan naik. Permasalahan yang dimiliki oleh perusahaan saat ini adalah sistem pendistribusian barang yang belum efisien karena biaya pengiriman tinggi. Hal itu dapat terjadi karena belum adanya perhatian dari segi penekanan biaya distribusi yang berubah setiap waktu yang disebabkan oleh adanya perubahan harga bahan bakar minyak (BBM) sampai biaya perawatan kendaraan distribusi yang dimiliki oleh perusahaan. Sehingga permasalahan tersebut menyebabkan profit dari perusahaan menjadi tidak optimal.

Pada Gambar. 1, dijelaskan bahwa jumlah pengiriman atau permintaan yang naik dari tahun 2016 ke tahun 2017 tetapi tejadi penurunan pada tahun 2018 dan tidak diikuti dengan menurunnya biaya pengiriman, melainkan terjadi kenaikan daripada tahun sebelumnya.

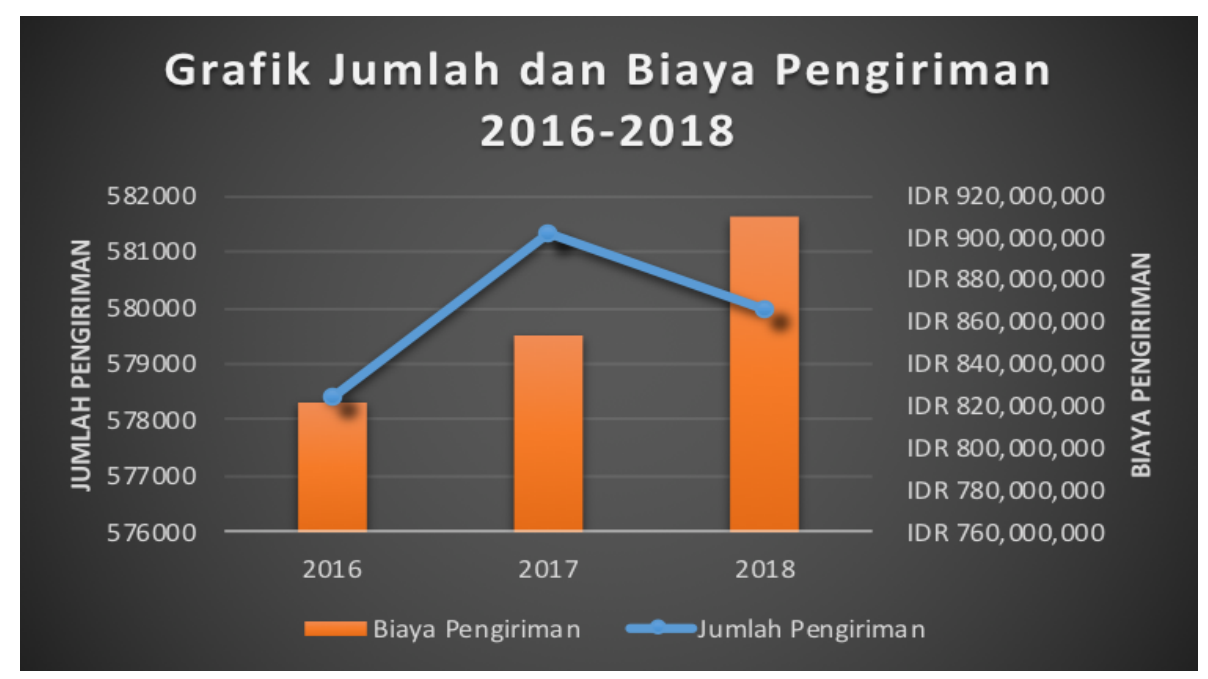

Gambar 1. Grafik Jumlah dan Biaya Pengiriman Tahun 2016-2018

Sumber: Perusahaan (2019)

Solusi alternatif terbaik untuk mengefisiensikan biaya dalam distribusi atau pengiriman barang yang dilakukan menggunakan angkutan sendiri atau jasa angkutan lain ke daerah-daerah tujuan, yaitu dengan menggunakan metode transportasi untuk memecahkan masalah dengan meminimalkan biaya pengiriman produk dari beberapa sumber ke beberapa tujuan (Heizer, dkk., 2017). Berdasarkan penelitian yang dilakukan oleh Azizah dan Suryawinata (2018) mengatakan bahwa metode transportasi menjadi salah satu metode penyelesaian untuk kasus dari beberapa sumber ke tujuan. Sedangkan Halawa, dkk. (2016) mengatakan bahwa meminimalkan biaya pengiriman barang dari satu lokasi ke lokasi lain adalah cara agar kebutuhan setiap daerah terpenuhi dan setiap lokasi pengiriman beroperasi dalam kapasitasnya. Dalam hal ini penulis ingin memberi saran untuk perusahaan dalam hal pengiriman barang. Apakah dengan metode yang sudah berjalan dari perusahaan sudah efisien atau sebaiknya menggunakan jasa angkutan lain akan lebih efisien? Penulis mengolah data dengan tiga vendor yang disebutkan oleh perusahaan, maka inilah yang menjadi alasan bagi penulis tertarik untuk menganalisis pendistribusian untuk mendapatkan biaya seminimal mungkin untuk mendapatkan keuntungan yang optimal bagi perusahaan. 


\section{Kajian Literatur}

\section{Distribusi}

Menurut Jacobs dan Chase (2016:8), distribusi disebut juga proses logistik. Jasa pengangkut dipilih untuk memindahkan produk ke gudang dan pelanggan, mengkoordinasikan dan menjadwalkan pergerakan barang dan informasi melalui jaringan pasokan, mengembangkan dan mengoperasikan suatu jaringan pergudangan, dan menjalankan sistem informasi yang mengelola penerimaan pesanan dari pelanggan dan sistem penagihan yang menagih pembayaran dari pelanggan.

Menurut Pujawan (2010:193-194), manajemen distribusi dan transportasi pada umumnya melakukan sejumlah fungsi dasar yang terdiri dari :

1. Melakukan segmentasi dan menentukan target service level.

2. Menentukan mode transportasi yang akan digunakan.

3. Melakukan konsolidasi informasi dan pengiriman.

4. Memberikan pelayanan nilai tambah.

5. Menyimpan persediaan.

6. Menangani pengembalian (return).

Menurut Assauri (2004), distribusi adalah kegiatan memindahkan produk dari sumber ke konsumen akhir dengan saluran distribusi pada waktu yang tepat. Menurut Soekartawi (2001), distribusi adalah aktivitas menyalurkan atau mengirimkan barang dan jasa supaya sampai hingga konsumen akhir. Menurut Swastha (2002), distribusi adalah saluran pemasaran yang dipakai oleh pembuat produk untuk mengirimkan produknya ke industri atau konsumen.

Secara umum definisi distribusi yaitu suatu proses atau kegiatan yang mempermudah pengiriman barang atau jasa dengan mengutamakan kepuasan pelanggan karena penggunaannya sesuai dengan yang diperlukan seperti jenis, jumlah, harga, dan lain-lain. Dan dengan distribusi atau pengiriman, produsen dapat mempertahankan serta mengembangkan kualitas produknya.

\section{Metode Transportasi}

Menurut Heizer, dkk. (2017:730), metode transportasi adalah suatu metode untuk memecahkan masalah yang bertujuan untuk minimalisasi biaya pengiriman produk dari beberapa sumber ke beberapa tujuan.

1. Menghitung jumlah pemesanan produk yang terjadi di dalam perusahaan.

2. Menentukan biaya yang akan dikeluarkan untuk mengantarkan barang melalui jasa angkutan ke tujuan.

3. Membuat model transportasi sehingga jelas terlihat asal, daerah tujuan, permintaan konsumen dan berapa banyak yang bisa ditampung jasa angkutan.

Menurut Sarjono (2010:70), metode transportasi merupakan salah satu teknik manajemen dalam mendistribusikan produk dari gudang ke tempat yang dituju. Metode transportasi sangat dibutuhkan oleh perusahaan yang melakukan kegiatan pengiriman barang dalam usahanya. Dengan adanya metode transportasi, perusahaan akan lebih efektif dan efisien dalam kegiatan pendistribusian produknya.

Menurut Andriansyah (2015:20), metode transportasi adalah salah satu kegiatan yang menyangkut peningkatan kebutuhan manusia, yakni dengan mengalokasikan barang dari satu tempat ke tempat lain yang berbeda. Menurut Hermanto, dkk., (2017:30), pengertian transportasi adalah kegiatan pemindahan barang dan manusia dari tempat asal ke tempat tujuan.

Transportasi menghasilkan produk yang disebut jasa transportasi. Keperluan akan jasa transportasi mengikuti perkembangan berbagai kegiatan yang terjadi di semua sektor ekonomi dan kehidupan masyarakat. Metode transportasi dapat memecahkan masalah pendistribusian barang dari sumber ke tujuan dengan biaya total distribusi minimum. Persoalan yang ingin dipecahkan oleh metode transportasi adalah menentukan distribusi barang untuk dapat meminimumkan biaya total distribusi.

Menurut Lestari dan Christy; (2018:51), metode transportasi adalah metode yang digunakan untuk mengatur distribusi dari sumber-sumber yang menyediakan produk yang sama ke tempat- 
tempat yang membutuhkan secara optimal. Alokasi produk ini harus diatur sedemikian rupa, karena terdapat perbedaan biaya-biaya alokasi dari satu sumber ke suatu tempat tujuan.

\section{Langkah-langkah Metode Transportasi}

Menurut Siswanto dalam Sarjono, (2010:72), model transportasi pada saat dikenali pertama kali, diselesaikan secara manual dengan menggunakan algoritma yang dikenal sebagai algoritma transportasi. Berikut adalah langkah-langkah analisis:

1. Diagnosis masalah dimulai dengan pengenalan sumber, tujuan, parameter, dan variabel.

2. Seluruh informasi tersebut kemudian dituangkan ke dalam matriks transportasi. Dalam hal ini informasi yang dibutuhkan adalah:

a. Bila kapasitas seluruh sumber lebih besar dari permintaan seluruh tujuan maka sebuah kolom semu (dummy) perlu ditambahkan untuk menampung kelebihan kapasitas itu.

b. Bila kapasitas seluruh sumber lebih kecil dari seluruh permintaan tujuan maka sebuah baris semu (dummy) perlu ditambahkan untuk menyediakan kapasitas semu (dummy) yang akan memenuhi kelebihan permintaan itu. Jelas sekali bahwa kelebihan permintaan itu tidak bisa dipenuhi.

3. Setelah matriks transportasi terbentuk kemudian dimulai menyusun tabel awal. Algoritma transportasi mengenal tiga macam metode untuk menyusun tabel awal, yaitu:

a. Metode biaya terkecil atau Least Cost Method.

b. Metode Sudut Barat Laut atau Northwest Corner Method.

c. VAM atau Vogel's Approximation Method.

Ketiga metode di atas masing-masing berfungsi untuk menentukan alokasi distribusi awal yang akan membuat seluruh kapasitas sumber teralokasi ke seluruh tujuan.

1. Setelah penyusunan tabel awal selesai maka sebagai langkah selanjutnya adalah pengujian optimalitas tabel untuk mengetahui apakah biaya distribusi total telah minimum. Secara sistematis, pengujian ini dilakukan untuk menjamin bahwa nilai fungsi tujuan minimum telah tercapai. Ada dua macam pengujian optimalitas algoritma transportasi, yaitu:

a. Stepping Stone Method.

b. MODI atau Modified Distribution Method.

2. Langkah yang terakhir adalah revisi tabel bila dalam langkah keempat terbukti bahwa tabel belum optimal atau biaya distribusi total masih mungkin diturunkan lagi. Dengan demikian, jelas sekali bahwa langkah kelima ini tidak akan dilakukan apabila pada langkah keempat telah membuktikan bahwa tabel telah optimal.

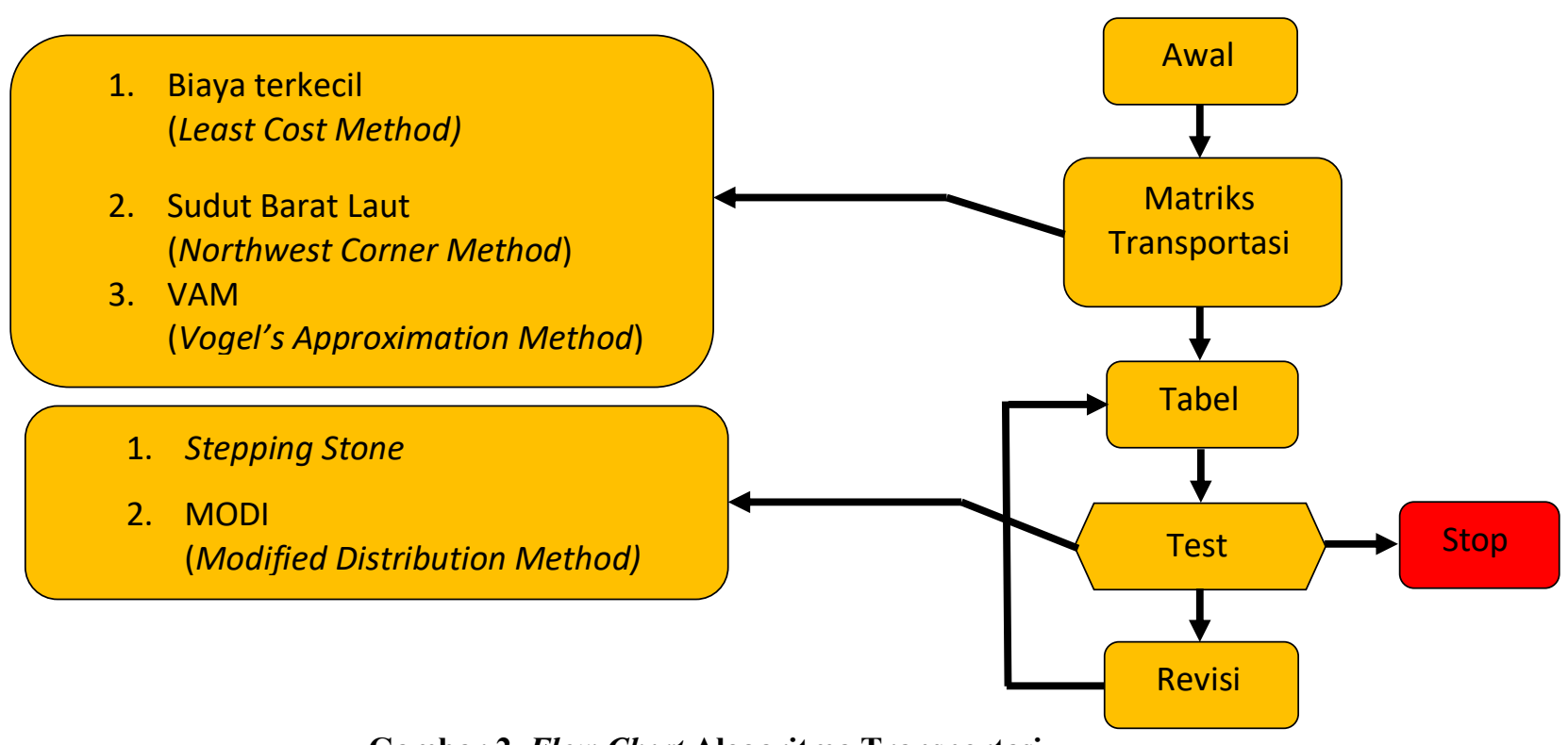

Gambar 2. Flow Chart Alogaritma Transportasi Sumber: Siswanto dalam Sarjono (2010:73) 


\section{Jenis-Jenis Metode Transportasi}

Berikut adalah jenis-jenis metode transportasi:

1. Metode North West Corner (NWC)

Menurut Heizer, dkk. (2017:732), pengertian metode North West Corner (NWC) adalah lokasi awal pengiriman produk dimulai dari sel kiri atas tabel (tepi barat daya) dan secara sistematis mengalokasikan unit ke rute pengiriman. Aturan di dalam metode North West Corner (NWC) melakukan perhitungan dimulai dari kiri atas tabel dan mengalokasikan unit ke rute pengiriman, sebagai berikut:

1. Menghabiskan supply (persediaan barang) dari setiap baris sebelum pindah ke baris berikutnya.

2. Menghabiskan demand (permintaan gudang) dari setiap kolom sebelum pindah ke kolom berikutnya di sebelah kanan.

3. Memeriksa dan memastikan bahwa semua persediaan dan pemintaan telah dipenuhi.

2. Metode Least Cost

Menurut Heizer, dkk. (2017:733), pengertian metode Least Cost adalah pendekatan berbasis biaya untuk menemukan solusi awal untuk masalah transportasi dengan dasar pemikiran dengan mengalokasikan ke sel-sel dengan biaya terendah. Langkah-langkah penyelesaian metode least cost sebagai berikut:

1. Mengidentifikasi sel dengan biaya yang terendah. Memutuskan ikatan apapun untuk biaya terendah secara sewenang-wenang.

2. Mengalokasikan unit sebanyak mungkin untuk sel tersebut tanpa melebihi demand dan supply. Kemudian coret kolom atau baris itu (atau keduanya) yang sudah penuh terisi.

3. Menemukan sel dengan biaya terendah dari sisa sel (yang belum dicoret).

4. Mengulangi langkah ke 2 dan 3 sampai semua unit setelah dialokasikan.

3. Vogel's Approximation Method

Menurut Sarjono, (2010:72), "tujuan dari jalur ini adalah untuk mempertahankan kendala penawaran dan permintaan sambil dilakukan alokasi ulang barang ke suatu kotak kosong". Menurut Siswanto dalam Sarjono, (2010:72), langkah-langkah di dalam Vogel's Approximation Method (VAM) sebagai berikut:

1. Membuat matrik yang menunjukkan kebutuhan masing-masing sumber dan biaya transportasi per unit.

2. Mencari selisih antara dua biaya terkecil di masing-masing kolom baris.

3. Memilih selisih terbesar di antara selisih-selisih yang telah dihitung pada langkah pertama.

4. Menyesuaikan penawaran dan permintaan untuk menunjukan alokasi yang sudah dilakukan. Hilangkan semua baris dan kolom dimana penawaran dan permintaan telah dihabiskan.

5. Jika semua penawaran dan permintaan belum dipenuhi, kembali ke langkah 1, jika semua penawaran dan permintaan solusi awal terperoleh.

\section{Isi Makalah}

Perhitungan dilakukan berdasarkan data yang sudah didapatkan dari perusahaan dengan menghitung biaya pengiriman dari beberapa jasa angkutan menuju ke pelanggan milik perusahaan dapat dilihat pada Tabel 2 di bawah ini: 
Analisis Efisiensi Biaya dengan Menggunakan Metode Transportasi pada Pendistribusian Barang PT. XYZ

Tabel 2. Biaya Transportasi

\begin{tabular}{|c|c|c|c|c|c|c|}
\hline Dari & JAKARTA & BOGOR & DEPOK & TANGERANG & BEKASI & SUPPLY \\
\hline Deliveree & 785 & 880 & 825 & 740 & 850 & 16.000 \\
\hline Sentral Cargo & 780 & 900 & 810 & 745 & 845 & 16.000 \\
\hline Bahana Cargo & 775 & 889 & 820 & 750 & 840 & 15.000 \\
\hline Demand & 11.550 & 8.650 & 8.500 & 10.260 & 9.370 & 48.330 \\
\hline
\end{tabular}

Sumber: Data dari Perusahaan (2019)

1. Metode North West Corner (NWC)

Gambar berikut adalah hasil pengolahan data dengan menggunakan metode NWC:

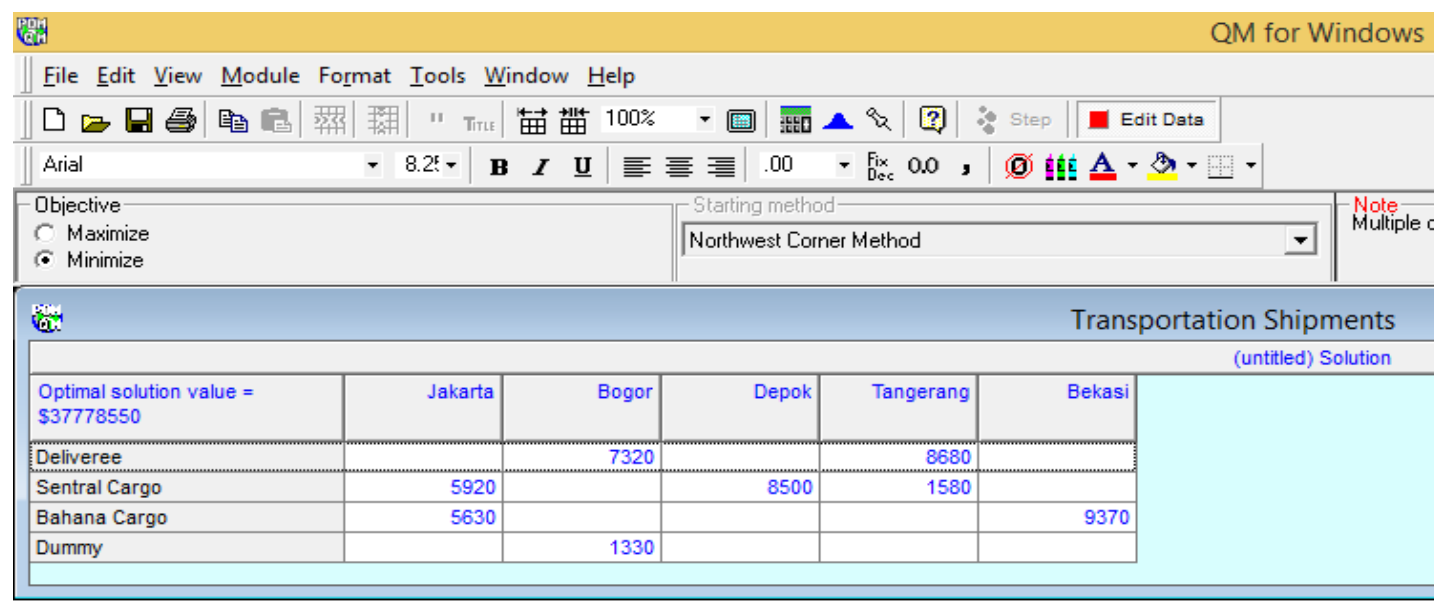

Gambar 3. Hasil Optimal dengan Menggunakan Metode NWC

Sumber: Hasil Pengolahan Data dengan Software QM for Windows V4 (2019)

Berikut hasil biaya optimal masing-masing jasa angkutan dengan metode NWC:

1. Daerah Jakarta dengan menggunakan 2 jasa angkutan yaitu jasa angkutan Sentral Cargo yang akan mengirimkan sebanyak $5.920 \mathrm{~kg}$ dengan biaya sebesar Rp $780 / \mathrm{kg}$ dan jasa angkutan Bahana Cargo yang akan mengirimkan sebanyak $5.630 \mathrm{~kg}$ dengan biaya sebesar $775 / \mathrm{kg}$. Maka biaya yang dibebankan untuk daerah Jakarta sebesar Rp 8.980.850,00. Biaya tersebut didapatkan dari jumlah barang yang akan dikirimkan dikalikan dengan biaya pengiriman barang per $\mathrm{kg}[(5.920 \times \mathrm{Rp} 780)+(5.630 \times \mathrm{Rp} 775)=\operatorname{Rp} 8.980 .850,00]$.

2. Daerah Bogor dengan menggunakan 1 jasa angkutan yaitu jasa angkutan Deliveree yang akan mengirimkan sebanyak $7.320 \mathrm{~kg}$ dengan biaya sebesar $\mathrm{Rp} 880 / \mathrm{kg}$. Maka biaya yang dibebankan untuk daerah Bogor sebesar Rp 6.441.600,00. Biaya tersebut didapatkan dari jumlah barang yang akan dikirimkan dikalikan dengan biaya pengiriman barang per $\mathrm{kg}$ $[(7.320 \times \mathrm{Rp} 880)=\mathrm{Rp} 6.441 .600]$.

3. Daerah Depok dengan menggunakan 1 jasa angkutan yaitu jasa angkutan Sentral Cargo yang akan mengirimkan sebanyak $8.500 \mathrm{~kg}$ dengan biaya sebesar Rp $810 / \mathrm{kg}$. Maka biaya yang dibebankan untuk daerah Depok sebesar Rp 6.885.000,00. Biaya tersebut didapatkan dari jumlah barang yang akan dikirimkan dikalikan dengan biaya pengiriman barang per $\mathrm{kg}$ $[(8.500 \times \operatorname{Rp} 810)=\operatorname{Rp} 6.885 .000]$. 
4. Daerah Tangerang dengan menggunakan 2 jasa angkutan yaitu jasa angkutan Deliveree yang akan mengirimkan sebanyak $8.680 \mathrm{~kg}$ dengan biaya sebesar $\mathrm{Rp} 740 / \mathrm{kg}$ dan jasa angkutan Sentral Cargo yang akan mengirimkan sebanyak $1.580 \mathrm{~kg}$ dengan biaya sebesar $745 / \mathrm{kg}$. Maka biaya yang dibebankan untuk daerah Tangerang sebesar Rp 7.600.300,00. Biaya tersebut didapatkan dari jumlah barang yang akan dikirimkan dikalikan dengan biaya pengiriman barang per $\mathrm{kg}[(8.680 \times \mathrm{Rp} 740)+(1.580 \times \mathrm{Rp} 745)=\mathrm{Rp} 7.600 .300]$.

5. Daerah Bekasi dengan menggunakan 1 jasa angkutan yaitu jasa angkutan jasa angkutan Bahana Cargo yang akan mengirimkan sebanyak $9.370 \mathrm{~kg}$ dengan biaya sebesar $840 / \mathrm{kg}$. Maka biaya yang dibebankan untuk daerah Bekasi sebesar Rp 7.870.800,00. Biaya tersebut didapatkan dari jumlah barang yang akan dikirimkan dikalikan dengan biaya pengiriman barang per $\mathrm{kg}[(9.370 \times \mathrm{Rp} 840)=\mathrm{Rp} 7.870 .800]$.

6. Untuk sisa pengiriman dari demand yang tidak terpakai, maka dialokasikan ke dalam dummy dan dummy tidak memiliki biaya pengiriman.

\section{Metode Least Cost}

Gambar berikut adalah hasil pengolahan data dengan menggunakan metode Least Cost:

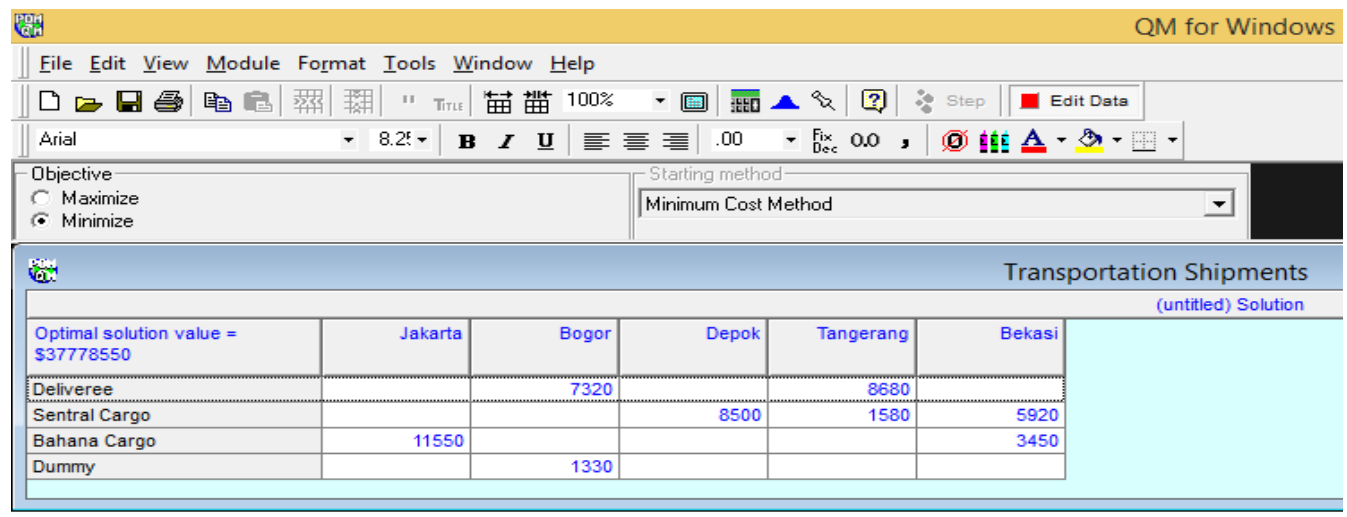

Gambar 4. Hasil Optimal dengan Menggunakan Metode Least Cost

Sumber: Hasil Pengolahan Data dengan Software QM for Windows V4 (2019)

Berikut hasil biaya optimal masing-masing jasa angkutan dengan metode least cost:

1. Daerah Jakarta dengan menggunakan 1 jasa angkutan yaitu jasa angkutan Bahana Cargo yang akan mengirimkan sebanyak $11.550 \mathrm{~kg}$ dengan biaya sebesar $775 / \mathrm{kg}$. Maka biaya yang dibebankan untuk daerah Jakarta sebesar Rp 8.951.250,00. Biaya tersebut didapatkan dari jumlah barang yang akan dikirimkan dikalikan dengan biaya pengiriman barang per $\mathrm{kg}$ $[(11.550 \times \mathrm{Rp} 775)=\mathrm{Rp} 8.951 .250]$.

2. Daerah Bogor dengan menggunakan 1 jasa angkutan yaitu jasa angkutan Deliveree yang akan mengirimkan sebanyak $7.320 \mathrm{~kg}$ dengan biaya sebesar Rp $880 / \mathrm{kg}$. Maka biaya yang dibebankan untuk daerah Bogor sebesar Rp 6.441.600,00. Biaya tersebut didapatkan dari jumlah barang yang akan dikirimkan dikalikan dengan biaya pengiriman barang per $\mathrm{kg}$ $[(7.320 \times \operatorname{Rp} 880)=\operatorname{Rp} 6.441 .600]$.

3. Daerah Depok dengan menggunakan 1 jasa angkutan yaitu jasa angkutan Sentral Cargo yang akan mengirimkan sebanyak $8.500 \mathrm{~kg}$ dengan biaya sebesar Rp $810 / \mathrm{kg}$. Maka biaya yang dibebankan untuk daerah Depok sebesar Rp 6.885.000,00. Biaya tersebut didapatkan dari jumlah barang yang akan dikirimkan dikalikan dengan biaya pengiriman barang per $\mathrm{kg}$ $[(8.500 \times \operatorname{Rp} 810)=\operatorname{Rp} 6.885 .000]$. 
4. Daerah Tangerang dengan menggunakan 2 jasa angkutan yaitu jasa angkutan Deliveree yang akan mengirimkan sebanyak $8.680 \mathrm{~kg}$ dengan biaya sebesar $\mathrm{Rp} 740 / \mathrm{kg}$ dan jasa angkutan Sentral Cargo yang akan mengirimkan sebanyak $1.580 \mathrm{~kg}$ dengan biaya sebesar $745 / \mathrm{kg}$. Maka biaya yang dibebankan untuk daerah Tangerang sebesar Rp 7.643.700,00. Biaya tersebut didapatkan dari jumlah barang yang akan dikirimkan dikalikan dengan biaya pengiriman barang per $\mathrm{kg}[(8.680 \times \mathrm{Rp} 740)+(1.580 \times \mathrm{Rp} 745)=\mathrm{Rp} 7.600 .300]$.

5. Daerah Bekasi dengan menggunakan 2 jasa angkutan yaitu jasa angkutan Sentral Cargo yang akan mengirimkan sebanyak $5.920 \mathrm{~kg}$ dengan biaya sebesar Rp $845 / \mathrm{kg}$ dan jasa angkutan Bahana Cargo yang akan mengirimkan sebanyak $3.450 \mathrm{~kg}$ dengan biaya sebesar $840 / \mathrm{kg}$. Maka biaya yang dibebankan untuk daerah Bekasi sebesar Rp 7.900.400,00. Biaya tersebut didapatkan dari jumlah barang yang akan dikirimkan dikalikan dengan biaya pengiriman barang per kg [(5.920 x Rp 845) + (3.450 x Rp 840) $=\operatorname{Rp~7.900.400].~}$

6. Untuk sisa pengiriman dari demand yang tidak terpakai, maka dialokasikan ke dalam dummy dan dummy tidak memiliki biaya pengiriman.

\section{Metode Vogel's Approximation (VAM)}

Gambar berikut adalah hasil pengolahan data dengan menggunakan metode VAM:

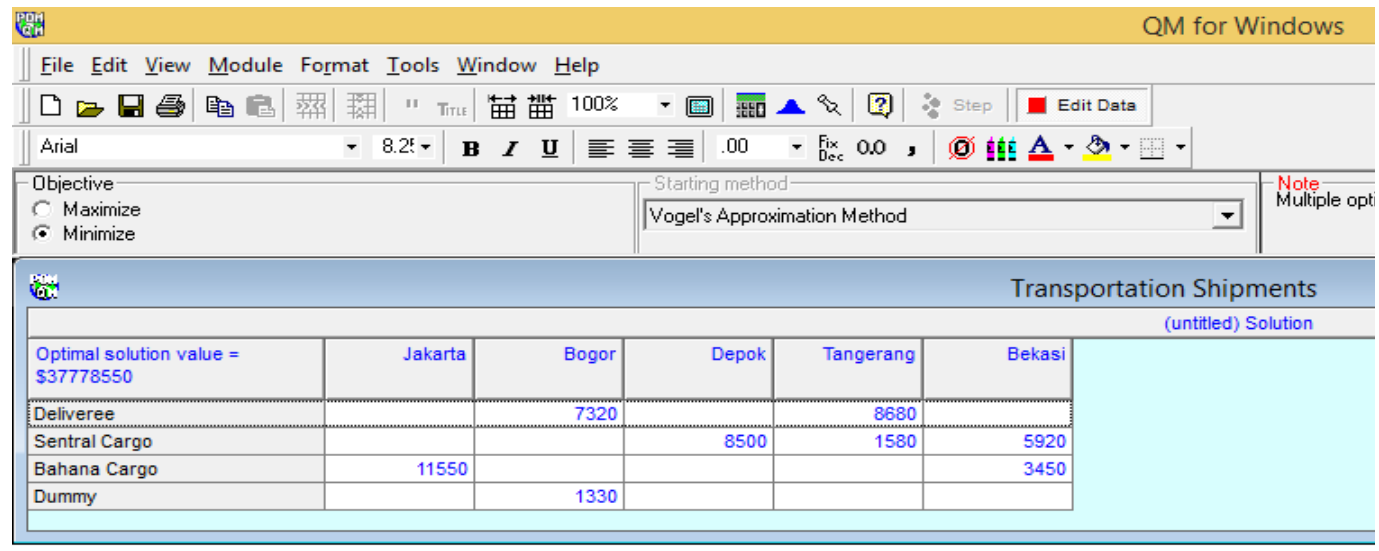

Gambar 5. Hasil Optimal dengan Menggunakan Metode VAM

Sumber: Hasil Pengolahan Data dengan Software QM for Windows V4 (2019)

Berikut hasil biaya optimal masing-masing jasa angkutan dengan metode VAM:

1. Daerah Jakarta dengan menggunakan 1 jasa angkutan yaitu jasa angkutan Bahana Cargo yang akan mengirimkan sebanyak $11.550 \mathrm{~kg}$ dengan biaya sebesar $775 / \mathrm{kg}$. Maka biaya yang dibebankan untuk daerah Jakarta sebesar Rp 8.951.250,00. Biaya tersebut didapatkan dari jumlah barang yang akan dikirimkan dikalikan dengan biaya pengiriman barang per $\mathrm{kg}$ $[(11.550 \times \mathrm{Rp} 775)=\mathrm{Rp} 8.951 .250]$.

2. Daerah Bogor dengan menggunakan 1 jasa angkutan yaitu jasa angkutan Deliveree yang akan mengirimkan sebanyak $7.320 \mathrm{~kg}$ dengan biaya sebesar Rp $880 / \mathrm{kg}$. Maka biaya yang dibebankan untuk daerah Bogor sebesar Rp 6.441.600,00. Biaya tersebut didapatkan dari jumlah barang yang akan dikirimkan dikalikan dengan biaya pengiriman barang per $\mathrm{kg}$ $[(7.320 \times \operatorname{Rp} 880)=\operatorname{Rp} 6.441 .600]$.

3. Daerah Depok dengan menggunakan 1 jasa angkutan yaitu jasa angkutan Sentral Cargo yang akan mengirimkan sebanyak $8.500 \mathrm{~kg}$ dengan biaya sebesar $\mathrm{Rp} 810 / \mathrm{kg}$. Maka biaya yang dibebankan untuk daerah Depok sebesar Rp 6.885.000,00. Biaya tersebut didapatkan dari jumlah barang yang akan dikirimkan dikalikan dengan biaya pengiriman barang per $\mathrm{kg}$ $[(8.500 \times \operatorname{Rp} 810)=\operatorname{Rp} 6.885 .000]$. 
4. Daerah Tangerang dengan menggunakan 2 jasa angkutan yaitu jasa angkutan Deliveree yang akan mengirimkan sebanyak $8.680 \mathrm{~kg}$ dengan biaya sebesar $\mathrm{Rp} 740 / \mathrm{kg}$ dan jasa angkutan Sentral Cargo yang akan mengirimkan sebanyak $1.580 \mathrm{~kg}$ dengan biaya sebesar $745 / \mathrm{kg}$. Maka biaya yang dibebankan untuk daerah Tangerang sebesar Rp 7.643.700,00. Biaya tersebut didapatkan dari jumlah barang yang akan dikirimkan dikalikan dengan biaya pengiriman barang per $\mathrm{kg}[(8.680 \times \mathrm{Rp} 740)+(1.580 \times \mathrm{Rp} 745)=\mathrm{Rp} 7.600 .300]$.

5. Daerah Bekasi dengan menggunakan 2 jasa angkutan yaitu jasa angkutan Sentral Cargo yang akan mengirimkan sebanyak $5.920 \mathrm{~kg}$ dengan biaya sebesar $\mathrm{Rp} 845 / \mathrm{kg}$ dan jasa angkutan Bahana Cargo yang akan mengirimkan sebanyak $3.450 \mathrm{~kg}$ dengan biaya sebesar $840 / \mathrm{kg}$. Maka biaya yang dibebankan untuk daerah Bekasi sebesar Rp 7.900.400,00. Biaya tersebut didapatkan dari jumlah barang yang akan dikirimkan dikalikan dengan biaya pengiriman barang per kg [(5.920 x Rp 845) + (3.450 x Rp 840) $=\operatorname{Rp~7.900.400].~}$

6. Untuk sisa pengiriman dari demand yang tidak terpakai, maka dialokasikan ke dalam dummy dan dummy tidak memiliki biaya pengiriman.

Tabel 3. Hasil Metode Transportasi

\begin{tabular}{|c|c|c|c|c|}
\hline Daerah & $\begin{array}{c}\text { Metode yang } \\
\text { sedang berjalan } \\
\text { (Rp) }\end{array}$ & $\begin{array}{c}\text { Metode NWC } \\
\text { (Rp) }\end{array}$ & $\begin{array}{c}\text { Metode Least Cost } \\
\text { (Rp) }\end{array}$ & $\begin{array}{c}\text { Metode VAM } \\
\text { (Rp) }\end{array}$ \\
\hline Jakarta & 18.130 .228 & 8.980 .850 & 8.951 .250 & 8.951 .250 \\
\hline Bogor & 13.578 .049 & 6.441 .600 & 6.441 .600 & 6.441 .600 \\
\hline Depok & 13.342 .592 & 6.885 .000 & 6.885 .000 & 6.885 .000 \\
\hline Tangerang & 16.105 .293 & 7.600 .300 & 7.600 .300 & 7.600 .300 \\
\hline Bekasi & 14.708 .245 & 7.870 .800 & 7.900 .400 & 7.900 .400 \\
\hline Total & $\mathbf{7 5 . 8 6 4 . 4 0 7}$ & $\mathbf{3 7 . 7 7 8 . 5 5 0}$ & $\mathbf{3 7 . 7 7 8 . 5 5 0}$ & $\mathbf{3 7 . 7 7 8 . 5 5 0}$ \\
\hline
\end{tabular}

Sumber: Hasil Pengolahan Data Penulis (2019)

Berdasarkan hasil perhitungan yang sudah dilakukan dan di dalam ilmu manajemen operasional yang sudah dijelaskan di atas serta hasil dari beberapa peneliti sebelumnya mengenai metode transportasi yang bertujuan untuk memecahkan masalah dan pengambilan keputusan perusahaan dalam distribusi barang serta menghitung biaya minimal pengiriman untuk bisa mendapatkan keuntungan yang optimal bagi perusahaan dengan menentukan menggunakan angkutan yang dimiliki sendiri atau menggunakan rekanan jasa angkutan berdasarkan kondisi area pelanggan yang dimiliki oleh perusahaan. Metode tranportasi yang digunakan bisa menjadi alternatif metode di dalam menentukan biaya pengiriman yang seefisien mungkin untuk mendapatkan keuntungan yang seoptimal mungkin.

Pada Tabel 3 dijelaskan bahwa perbandingan antara metode yang digunakan oleh perusahaan saat ini dibandingkan dengan metode transportasi yang sudah dilakukan penelitian secara langsung dari data yang dimiliki oleh perusahaan terdapat selisih biaya sebesar Rp. 38.085.857,00 dengan kata lain metode ini memberikan efisiensi sebesar 50,2\% kepada perusahaan.

Dalam beberapa kondisi di dalam dunia industri untuk proses pengiriman barang ke pelanggan dengan menggunakan 3 metode transportasi di atas harus dihitung berdasarkan jumlah barang yang dikirim ke pelanggan serta harga yang diberikan oleh jasa rekanan, dan biaya paling minimal yang dipilih dari 3 alternatif metode transportasi tersebut. 
Analisis Efisiensi Biaya dengan Menggunakan Metode Transportasi

pada Pendistribusian Barang PT. XYZ

\section{Kesimpulan dan Saran}

\section{Kesimpulan}

Berdasarkan hasil perhitungan dari penelitian ini dapat disimpulkan sebagai berikut :

1. Biaya pengiriman optimal barang pada perusahaan dengan menggunakan metode transportasi yang menggunakna jasa angkutan berupa pendekatan metode North West Corner, Least Cost, dan Vogel's Approximation adalah sebesar Rp 37.778.550,00. Serta biaya dengan metode yang sedang berjalan menggunakan angkutan sendiri adalah sebesar Rp 75.864.407,00. Berdasarkan perhitungan dan analisa yang diperoleh, metode yang sedang berjalan di perusahaan belum optimal dan efisien karena dengan menggunakan salah satu metode transportasi perusahaan akan mengefesiensikan biaya sebesar Rp 38.085.857,00.

2. Solusi yang sebaiknya dipilih oleh perusahaan adalah menggunakan rekanan jasa angkutan dikarenakan perusahaan akan mendapatkan hasil biaya yang optimal dan efisiensi dibandingkan menggunakan angkutan sendiri dengan metode yang sedang berjalan saat ini.

\section{Saran}

Saran yang bisa diberikan berdasarkan hasil penelitan sebagai berikut:

1. Perusahaan sebaiknya menggunakan salah satu pendekatan metode transportasi yaitu di antaranya North West Corner, Least Cost, dan Vogel's Approximation untuk mendapatkan biaya yang lebih efisien agar perusahaan mendapatkan profit yang lebih optimal atau maksimal.

2. Perusahaan lebih baik mulai mempertimbangkan menggunakan rekanan jasa angkutan untuk daerah Jabodetabek, karena berdasarkan hasil penelitian dengan menggunakan perhitungan metode transportasi dengan rekanan jasa angkutan sehingga perusahaan bisa mendapatkan biaya yang lebih efisien.

3. Karena keterbatasan data yang didapat dalam penelitian ini, untuk penelitian selanjutnya dapat melakukan penelitian dengan menggunakan 3 metode ini dengan pengujian beberapa area pengiriman antar pulau serta beberapa rekanan jasa angkutan dan perbandingan biaya menggunakan jarak untuk mencari alternatif metode mana yang dipilih perusahaan dan rekanan jasa angkutan mana yang dipilih.

\section{Daftar Pustaka}

Andriansyah. (2015). Manajemen Transportasi dalam Kajian dan Teori. Jakarta: Fakultas Ilmu Sosial dan Ilmu Politik Universitas Prof. Dr. Moestopo Beragama. Retrieved from https://moestopo.ac.id/wp-content/uploads/2016/05/Manajemen-Transportasi-DalamKajian-Dan-Teori-Oleh-Dr.-Andriansyah.-M.Si_.pdf

Assauri, S. (2004). Manajemen Pemasaran. Jakarta: Rajawali Press.

Azizah, N. L., \& Suryawinata, M. (2018, March). Aplikasi Metode Transportation dalam Optmasi Biaya Distribusi Beras Sejahtera pada Perum Bulog Sub-Drive Sidoarjo. Soulmath, Vol. 6 No. 1.

Halawa, M. I., Maatuk, A. M., Idrees, H. S., \& Ali, E. H. (2016). An Optimal Solution for Transportation Problem Using Computing Modelling. The Internet of Things (IoT) Conference.

Heizer, J., Render, B., \& Munson, C. (2017). Operation Management Sustainability and Supply Chain Management (Twelfth ed.). Jakarta: Pearson.

Hermanto, N., Hermaliani, E. H., \& Sutinah, E. (2017). Vogel's Aproximation Method dalam Optimalisasi Biaya Transportasi Pengiriman Koran pada PT. Arah Medialog Pembangunan. Jurnal Teknik Komputer AMIK BSI, Vol. 3 No. 1.

Lestari, O. D., \& Christy, T. (2018, December). Analisis Perbandingan Pengiriman Barang Menggunakan Metode Vogel's Approximation Method (VAM) dan Modified Distribution (MODI). JURTEKSI (Jurnal Teknologi dan Sistem Informasi, Vol. 5 No. 1, hal. 51-58. 
Analisis Efisiensi Biaya dengan Menggunakan Metode Transportasi pada Pendistribusian Barang PT. XYZ

Jacobs, F. R., \& Chase, R. B. (2016). Manajemen Operasi dan Rantai Pasokan (14 ed.). Jakarta: Salemba Empat.

Pujawan, I.N. dan Mahendrawathi (2010). Supply Chain Management. Surabaya: Guna Widya. Sarjono, H. (2010). Aplikasi Riset Operasi. Jakarta: Salemba Empat.

Soekartawi (2001). Pengantar Agroindustri. Jakarta: Raja Grapindo Persada.

Swastha, B. (2002). Manajemen Pemasaran (Edisi Kedua, Cetakan Kedelapan). Jakarta: Liberty. 